[J. Appl. Glycosci., Vol. 49, No. 2, p. 99-106 (2002)]

\title{
Purification and Characterization of Pectate Lyase I and II from Fungus Stereum purpureum
}

\author{
Kazuo Miyairi, ${ }^{*}$ Kaori Nishida, Masaru Takarae, Yumiko Shikanai and Toshikatsu Okuno \\ Department of Biochemistry and Biotechnology, Faculty of Agriculture and Life Science, Hirosaki University \\ (3, Bunkyo-cho, Hirosaki 036-8561, Japan)
}

\begin{abstract}
Two pectate lyases (PLs I and II) were isolated from the culture filtrate of Stereum purpureum, the causative fungus of apple silver-leaf disease. The lyases were isolated using DE52 column chromatography, and their molecular masses were estimated to be $48 \mathrm{kDa}$ by SDS-PAGE. After treatment with endo- $\beta-N$-acetylglucosaminidase (Endo $\mathrm{H}$ ), their molecular masses decreased equally to $38 \mathrm{kDa}$, indicating that these PLs are glycoproteins. The $\mathrm{p} I$ values for PLs I and II were determined to be 4.15 and 4.10, respectively. The amino acid compositions of PLs I and II were very similar, and furthermore the amino acid sequences of the $\mathrm{N}$-terminal 20 residues of the two enzymes were identical. Their optimum $\mathrm{pH}$ values, and thermal and $\mathrm{pH}$ stabilities were 9.5 , up to $50^{\circ} \mathrm{C}$, and $\mathrm{pH} 6-7$, respectively. Both PLs I and II required $0.2 \mathrm{mM} \mathrm{Ca}^{2+}$ ion for maximum activity. The enzymes were assigned as endo-types because of the detection of oligo-GalUAs as products from the initial reaction. However they mainly formed products less than octa-GalUA in degree of polymerization. Erwinia carotovora PL mainly formed products more than octa-GalUA. Therefore they were different in their initial reaction products. As in the case of the E. carotovora PL, the final products of $S$. purpureum PL were 4,5-unsaturated di- and tri-GalUA.
\end{abstract}

During our studies on endopolygalacturonases (endoPG) produced by the fungus Stereum purpureum, ${ }^{1-3)}$ which causes silver-leaf symptoms on apple leaves, it was discovered that this fungus produces pectate lyase (PL) in its culture filtrate. ${ }^{4)}$ PLs split the glycosidic bond by trans-elimination of the hydrogen from the C-4 and C-5 positions of the aglycone portion of the substrate, and are classified fundamentally into two types, endoPL (EC 4.2.2.2) and exoPL (EC 4.2.2.9). Another type of enzyme with terminal mechanism is oligogalacturonate lyase (EC 4.2.2.6) which catalyses the production of 4-deoxy-L-threo-hexos-5-ulosuronate by eliminative removal of the terminal residues reduced from oligo-GalUA. PLs are microbial extracellular enzymes, and those from the genera $E r$ -

\footnotetext{
${ }^{*}$ To whom correspondence should be addressed (Km124 @ cc.hirosaki-u.ac.jp).

Abbreviations: PL, pectate lyase; DP, degree of polymerization; AIPA, acid-insoluble polygalacturonate; GalUA, galacturonic acid; unsatd. GalUA, 4,5-unsaturated GalUA; Endo $\mathrm{H}$, endo- $\beta-N$-acetylglucosaminidase.
}

winia $^{5,6)}$ and Bacillus ${ }^{7,8)}$ are well known due to softrot symptoms in plants. Furthermore, they are also found in other microorganisms, including Pseudomonas, ${ }^{9,10)}$ Xanthomonas, ${ }^{11)}$ Aspergillus, ${ }^{12)}$ Fusarium $^{13)}$ and Rhizoctonia. ${ }^{14)}$ Although clonings of fungal PLs were reported for Aspergillus nidulans $^{12)}$ and $F$. solani, ${ }^{15)}$ their enzymatic properties have been relatively unknown. Recently the role of $\mathrm{Ca}^{2+}$ ions in substrate binding using recombinant PL A of $A$. niger was discussed. ${ }^{16)}$ In PL studies, the elucidation of the enzymatic properties of the fungal type is important. In this paper, we describe the purification of two PLs from fungus S. purpureum, and their properties, especially in comparison to those of Erwinia carotovora.

\section{MATERIALS AND METHODS}

Microorganism and cultivation. The S. purpureum Persoon (ASP-4B) used in this study was supplied by the Aomori Apple Experiment Station 
and maintained by subculture on an agar medium. Medium for PL production was composed of potato decoction liquor (from $150 \mathrm{~g}$ of potato/L) containing $10 \% \quad \mathrm{~V} 8$ vegetable juice (Campbell Soup Co.). The mycelia were inoculated into 100 $\mathrm{mL}$ of culture in $500 \mathrm{~mL}$ Erlenmeyer flask. The cultivation was carried out at $28^{\circ} \mathrm{C}$ for $c a .13$ days without shaking.

Preparation of substrates. Pectic acid was prepared from commercial citrus pectin (Wako Pure Chemical Industries, Ltd.) by alkaline saponification. Acid-insoluble polygalacturonic acid (AIPA) was prepared from the commercial citrus pectin by partial acid hydrolysis method of Ozawa. ${ }^{17)}$ The AIPA was free from neutral sugars and $\overline{\mathrm{DP}}$ was estimated to be 43 . Unsatd. di-, tri-, tetra-, penta-, hexa-, hepta- and octa-GalUA used as standard for identification of unsatd. oligoGalUAs produced in HPLC were prepared from AIPA by enzyme degradation with endoPL from E. carotovora ${ }^{17,18)}$

Enzyme activity assay and protein measurement. The enzyme reaction for PL was done at $\mathrm{pH} 9.0$ for appropriate lengths of times using a $0.1 \%$ AIPA reaction solution containing $0.3 \mathrm{mM}$ $\mathrm{Ca}^{2+}$. The activity was assayed by measuring the amount of released 4-deoxy-4,5-dehydro-D-galactosyl groups with absorbance at $235 \mathrm{~nm}$. One unit of PL activity was defined as the amount of the enzyme that produces $1 \mu \mathrm{mol} 4,5$-unsaturated product $\min ^{-1}$ at $30^{\circ} \mathrm{C}$ under the assay conditions described. A molar extinction coefficient of $4.7 \times 10^{3}$ $\mathrm{M}^{-1} \mathrm{~cm}^{-1}$ was used for calculation. ${ }^{19)} \mathrm{PG}$ and pectinesterase activities were determined according to the previously described methods. ${ }^{18)}$

The protein concentration was assayed by the method of Lowry et al ${ }^{20)}$ with bovine serum albumin (Sigma) as a standard. Absorbance at $280 \mathrm{~nm}$ was used to monitor protein in column chromatography.

Purification of PLS I and II. S. purpureum was cultivated for 13 days at $28^{\circ} \mathrm{C}$ by stationary culture. The culture filtrate obtained was purified by the following procedures. All operations were carried out at temperatures below $5^{\circ} \mathrm{C}$.

Step 1. Adsorption on CM52 and DE52 mixture column. The culture filtrate $(3.8 \mathrm{~L})$ was di- luted 3 times with dist. water and adsorbed on a CM52 and DE52 (Whatman, USA) mixture column $(6.0 \times 22 \mathrm{~cm})$. The adsorbed protein was eluted by $20 \mathrm{mM}$ phosphate buffer ( $\mathrm{pH} 7.5$ ) containing $300 \mathrm{~mm} \mathrm{NaCl}$, followed by dialysis against $20 \mathrm{~mm}$ phosphate buffer $(\mathrm{pH}$ 6.3) and then about $800 \mathrm{~mL}$ of the dialysate was lyophilized.

Step 2. 1st DE52 column chromatography. The lyophilized crude preparation was dissolved

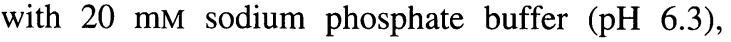
and the solution was dialyzed against the same buffer. The enzyme solution was applied to a DE52 column $(6.0 \times 24 \mathrm{~cm})$ equilibrated with the same buffer. After the column was washed with 2 bed volumes of the buffer, PLs were eluted with the same buffer containing $50 \mathrm{mM} \mathrm{NaCl}$. The active fractions were pooled, concentrated to $50 \mathrm{~mL}$ by ultrafiltration, and dialyzed against $20 \mathrm{~mm}$ sodium acetate buffer ( $\mathrm{pH}$ 5.3).

Step 3. Second DE52 column chromatography. The enzyme solution was applied to a DE52 column $(3.0 \times 80 \mathrm{~cm})$ equilibrated with 20 mM phosphate buffer ( $\mathrm{pH}$ 6.3). After the column was washed with $1 \mathrm{~L}$ of the starting buffer, the adsorbed enzyme was eluted by a linear gradient of 0 to $100 \mathrm{mM} \mathrm{NaCl}$ in the same buffer. The two active fractions were individually combined and each was concentrated to $10 \mathrm{~mL}$ by ultrafiltration.

\section{Step 4. Gigapite column chromatography.}

The enzyme solutions from step 3 were dialyzed against $2 \mathrm{~mm}$ sodium phosphate buffer $(\mathrm{pH}$ 6.5) and then applied to a Gigapite (Seikagaku Kogyo Co.) column $(2 \times 30 \mathrm{~cm})$ equilibrated with the same buffer. The column was washed with 250 $\mathrm{mL}$ of the starting buffer, PLs were eluted with a linear gradient of 2 to $200 \mathrm{~mm}$ of the same buffer. The active fractions were collected and lyophilized.

Step 5. Sephadex G-100 gel filtration. PLs obtained by step 4 were dissolved in $2 \mathrm{~mL}$ of 50 $\mathrm{mM}$ phosphate buffer ( $\mathrm{pH}$ 7.2) containing $100 \mathrm{mM}$ $\mathrm{NaCl}$ and applied to a Sephadex G-100 (Pharmacia LKB) column $(3 \times 95 \mathrm{~cm})$ equilibrated with the same buffer. After the active fractions were concentrated, they were dialyzed against $20 \mathrm{mM}$ sodium acetate buffer ( $\mathrm{pH}$ 6.5), lyophilized and stocked at $-40^{\circ} \mathrm{C}$. 
Electrophoretic analysis. Sodium dodesyl sulfate (SDS)-PAGE (12.5\% acrylamide gel) was performed by the method of Laemmli. ${ }^{21)}$ Proteins in the gel were stained with Coomassie Brilliant Blue R-250 (CBB). A calibration kit (Boehringer Mannheim) was used as standard molecular mass markers.

Isoelectric focusing was done using an Atto AE3235 apparatus. ${ }^{22)}$ Slab gels contained $7.5 \%(\mathrm{w} / \mathrm{v})$ acrylamide, and $0.3 \%$ Ampholine (pH 3-10, Pharmacia Biotech.). Isoelectric points was measured using a $\mathrm{p} I$ marker protein kit $(\mathrm{pH} \mathrm{3-10,} \mathrm{Pharmacia}$ Biotech.) as standard $\mathrm{p} I$ markers.

Lectin staining of PLs. After SDS-PAGE of PLs, the gel was transferred to a PVDF membrane (Immobilon-P, Millipore, Tokyo) by electroblotting. The membrane was incubated with Peroxidase-ConA, and the protein bands containing ConA-reactive sugar chains were visualized.

Deglycosylation of PLs. Sugar moiety of enzyme was removed by enzymatic hydrolysis with Endo H (New England Biolabs). Twenty $\mu \mathrm{g}$ of desalted PL I or II were dissolved in $20 \mu \mathrm{L}$ of denaturing buffer, boiled for $10 \mathrm{~min}$, and then $3 \mu \mathrm{L}$ of $500 \mathrm{mM}$ citrate buffer $(\mathrm{pH} 5.5)$ and $150 \mathrm{U} / 0.3$ $\mu \mathrm{L}$ of Endo $\mathrm{H}$ were added. Each reaction mixture was incubated overnight at $35^{\circ} \mathrm{C}$, and the deglycosylated PL was lyophilized.

$N$-terminal amino acid sequencing. The proteins from the SDS-polyacrylamide gel were electrophoretically transferred to a PVDF membrane (Immobilon-P, Millipore). After staining with CBB, the area of PL I or II bands was cut and destained with a $50 \%$ solution of $\mathrm{EtOH}$. Each membrane piece was used to determine the amino acid sequence by an automated protein sequencer (PPSQ-10, Shimadzu Co.).

Cultivation of $E$. carotovora and purification of its PL. E. carotovora (IFO No. 14082 isolate) used in this study was supplied by the Osaka Fermentation Experiment Station. This was cultivated, with shaking, for $48 \mathrm{~h}$ at $27^{\circ} \mathrm{C}$. The culture medium used was composed of $0.5 \%$ pectin, $0.5 \% \mathrm{~L}$ glutamine, $0.3 \% \quad\left(\mathrm{NH}_{4}\right)_{2} \mathrm{SO}_{4}, \quad 0.24 \% \quad \mathrm{KH}_{2} \mathrm{PO}_{4}$, $0.08 \% \mathrm{Na}_{2} \mathrm{HPO}_{4}, 0.05 \% \mathrm{MgSO}_{4} \cdot 7 \mathrm{H}_{2} \mathrm{O}$ and $0.02 \%$ $\mathrm{CaCl}_{2 .}{ }^{23)}$ The purification of enzymes did not exceed $5^{\circ} \mathrm{C}$. The culture $(9 \mathrm{~L})$ was centrifuged $\left(11,000 \mathrm{~g}, 15 \mathrm{~min}, 4^{\circ} \mathrm{C}\right)$, concentrated by ultrafiltration (PM-10, Millipore) and dialyzed against 2 mM phosphate buffer ( $\mathrm{pH} 7.0$ ) for $10 \mathrm{~h}$, and the crude preparation was lyophilized. The lyophilizate was dissolved in $20 \mathrm{mM}$ sodium phosphate buffer (pH 7.0) and dialysed against the same buffer. The enzyme solution was applied to a 1st CM52 column $(5.3 \times 20 \mathrm{~cm})$ equilibrated with the same buffer. After the column was washed with 2 bed volumes of the buffer, PLs were eluted with the same buffer containing $200 \mathrm{mM} \mathrm{NaCl}$. The active fractions were pooled, concentrated to $20 \mathrm{~mL}$ by ultrafiltration, and dialyzed against $20 \mathrm{~mm}$ sodium acetate buffer ( $\mathrm{pH} 7.0)$. The enzyme solution was applied to a CM52 column $(3.0 \times 80 \mathrm{~cm})$ equilibrated with $20 \mathrm{mM}$ phosphate buffer ( $\mathrm{pH} 7.0)$. After the column was washed with $1 \mathrm{~L}$ of the starting buffer, the adsorbed enzyme was eluted by a step wise elution of 0 to $200 \mathrm{mM} \mathrm{NaCl}$ in the same buffer. The two active fractions (PLs I and II) eluted by $50 \mathrm{mM}$ of $\mathrm{NaCl}$ were collected separately and lyophilized. These PLs were homogeneous in SDS-PAGE. In this study, PL I was used.

Analysis of amino acid composition. The amino acid compositions of their enzymes were analyzed by an AccQ TagTM amino acid analysis using an HPLC system (Waters).

Analysis of reaction products. The reaction mixture $(1 \mathrm{~mL})$ containing $0.1 \%$ AIPA, $0.3 \mathrm{mM}$ $\mathrm{Ca}^{2+}$ ion, $50 \mathrm{mM}$ Tris-HCl buffer (pH 9.0) and PL $(0.012 \mathrm{U})$ was incubated at $30^{\circ} \mathrm{C}$, and $100 \mu \mathrm{L}$ samples were withdrawn at $2,10 \mathrm{~min}$ and $12 \mathrm{~h}$. Each enzyme reaction was stopped by lowering the $\mathrm{pH}$ with Dowex $50 \mathrm{~W} \times 8$ and used for HPLC analysis (Waters) using a Shodex Sugar SH1821 column $(0.8 \times 30 \mathrm{~cm})$ connected with a Shodex Sugar SH1011P guard column $(0.6 \times 3 \mathrm{~cm})$ (Showa Denko Co.). The detections of products were followed at $A_{235}$. The elution was carried out with $0.005 \mathrm{NH}_{2} \mathrm{SO}_{4}$ at $40^{\circ} \mathrm{C}$ at $0.5 \mathrm{~mL} / \mathrm{min}^{24)}$

\section{RESULTS AND DISCUSSION}

\section{Production of PL by S. purpureum.}

The production of PL was induced by adding either $0.5 \%$ pectin or $10 \% \mathrm{~V} 8$ vegetable juice. As a result, PL activity was significantly higher with 


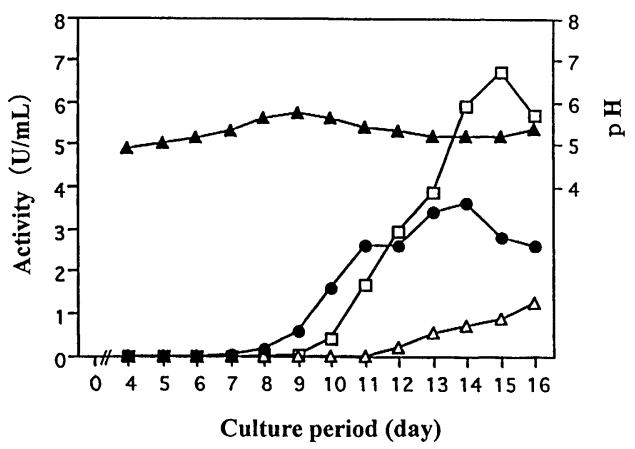

Fig. 1. Time course of PL production by $S$. purpureum.

Potato decoction liquor containing $10 \%$ V8 vegetable juice was used as the medium for PL production. Each enzyme activity was assayed under the conditions described in MATERIAls AND METHOdS. Symbols: O, PL activity; $\triangle$, PE activity; $\square$, PG activity $(\times 10 \mathrm{U}) ; \boldsymbol{\Delta}, \mathrm{pH}$ of the medium.

the addition of the vegetable juice. The PL production as a function of time is shown in Fig. 1. PL activity was initially detected after an 8-day incubation, and attained the highest value after 14 days. Comparatively, PL production preceded PG production; PG showed the maximum activity on the 15th day. Aside from these activities, the filtrate indicated a low activity of pectin lyase.

\section{Purification of PLS I and II.}

In the first DE52 column chromatography, two PL isozymes, assigned as PLs I and II, were eluted using $20 \mathrm{mM}$ phosphate buffer ( $\mathrm{pH}$ 6.3) containing

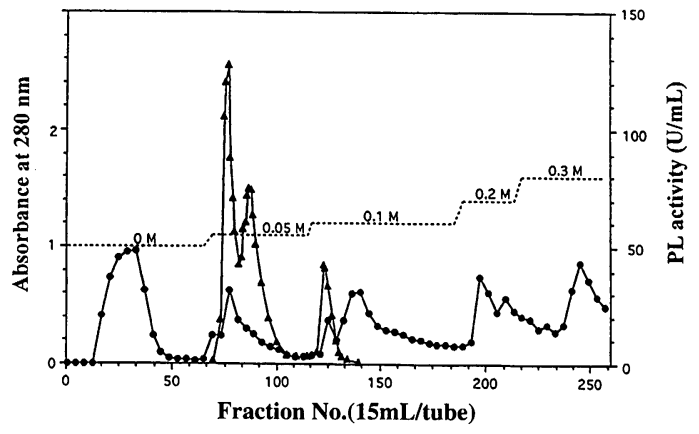

Fig. 2. First DE52 column chromatography of PLs I and II from $S$. purpureum.

The chromatography was carried out under the conditions described in MATERIALS AND METHODS. Each fraction $(15 \mathrm{~mL})$ was assayed for protein $\left(\bigcirc, A_{280}\right)$ and PL activity $\left(\bigcirc, A_{235}\right)$.

$50 \mathrm{mM} \mathrm{NaCl}$ as shown in Fig. 2. Further elution with $100 \mathrm{mM} \mathrm{NaCl}$ yielded additional PL activities, but they were not further purified and characterized in this study. The two PL-active fractions eluted with $50 \mathrm{mM} \mathrm{NaCl}$ were pooled and subjected to a second DE52 column chromatography. The resulting PLs I and II fractions were separately pooled. They were purified separately using Gigapite chromatography. PL I or II was weakly adsorbed on the Gigapite column, and was eluted at around $20 \mathrm{mM}$ sodium phosphate buffer $(\mathrm{pH}$ 6.5). In the final purification step using Sephadex G-100 gel filtration, each PL-active fraction was eluted as a single peak. The specific activities of

Table 1. Purification of PLs I and II from S. purpureum.

\begin{tabular}{lccccc}
\hline \multicolumn{1}{c}{ Step } & $\begin{array}{c}\text { Total activity } \\
(\mathrm{U})\end{array}$ & $\begin{array}{c}\text { Total protein } \\
(\mathrm{mg})\end{array}$ & $\begin{array}{c}\text { Specific activity } \\
(\mathrm{U} / \mathrm{mg})\end{array}$ & $\begin{array}{c}\text { Purification } \\
(- \text { fold })\end{array}$ & $\begin{array}{c}\text { Recovery } \\
(\%)\end{array}$ \\
\hline Culture filtrate & 85000 & 8700 & 9.8 & 1.0 & 100 \\
DE · CM adsorption & 56800 & 2300 & 25 & 2.5 & 67 \\
1st DE52 & 43350 & 250 & 173 & 18 & 51 \\
2nd DE52 & & & & & \\
$\quad$ PL I & 12700 & 51 & 249 & 25 & 15 \\
$\quad$ PL II & 17100 & 52 & 330 & 35 & 20 \\
Gigapite & & & & & \\
PL I & 10500 & 35 & 300 & 31 & 13 \\
PL II & 13000 & 42 & 310 & 32 & 14 \\
Sephadex G-100 & & & & & \\
$\quad$ PL I & 5600 & 13 & 448 & 46 & 6.6 \\
PL II & 8000 & 19 & 421 & 43 & 9.4 \\
\hline
\end{tabular}


PLs I and II toward AIPA were 448 and 421, respectively. The specific activity of purified $E$. carotovora PL I was 353. A typical purification of enzymes is summarized in Table 1.

\section{Purity, molecular mass, and isoelectric point.}

The purity of these enzymes was verified using SDS-PAGE and IEF. The SDS-PAGE analysis of PLs I and II indicated a single band corresponding to a molecular mass of $48 \mathrm{kDa}$ for both (Fig. 3). SDS-PAGE of the purified E. carotovora PL I indicated a homogenous enzyme with a molecular mass of $42 \mathrm{kDa}$ (Fig. 3). The analytical IEF showed that PLs I and II also gave a single band, and the $\mathrm{p} I$ values were estimated as 4.1 for PL I and 4.15 for PL II (Fig. 4). Except for one of the five PLs from E. chrysanthemi, which has an acidic $\mathrm{p} I{ }^{25)}$ the isoelectric points of all bacterial $\mathrm{PL}$ reported to date are alkaline. ${ }^{26)}$

\section{Detection of sugar chain.}

The bands of PLs on the SDS-PAGE were subjected to lectin-staining using peroxidase-ConA. After deglycosylation with Endo $\mathrm{H}$, the molecular masses decreased from 48 to $38 \mathrm{kDa}$ (Fig. 5), which indicated that the two PLs are glycosylated proteins that have specific sugar chains for ConA. The PL isolated from $F$. moniliformae was reported also as a glycoprotein with $5 \%$ carbohydrate content. $^{27)}$

\section{$N$-terminal amino acid sequences.}

The $N$-terminal amino acid sequence of the two PLs were identical for 20 amino acid residues as follows: ASVDEVATVGFAGLAGVQGG

This $N$-terminal amino acid sequence has no similarity at all to the known sequences of pectic enzymes.

\section{Analysis of amino acid composition.}

As shown in Table 2, the amino acid compositions of PLs I and II are almost identical. Further, the compositions were similar to that of the purified PL I isolated from E. carotovora, and to those of endopolygalacturonase from S. purpureum and Fomitopsis cytisina. $^{28)}$

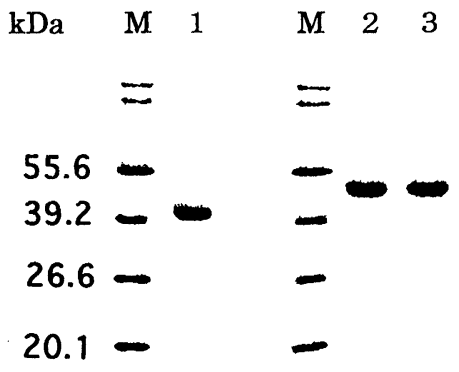

Fig. 3. SDS-PAGE of purified PLs I and II from $S$. purpureum and PL I from E. carotovora.

Each sample was electrophoresed on an SDSpolyacrylamide gel. Lane $\mathrm{M}$, molecular mass marker proteins; lane 1, E. carotovora PL I; lane 2, S. purpureum PL I; lane 3, S. purpureum PL II. Numbers at the left indicate molecular mass markers in $\mathrm{kDa}$.

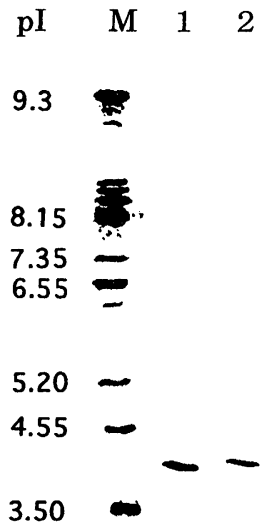

Fig. 4. IEF of purified PLs I and II from S. purpureum.

Each sample was electrophoresed on a IEF. Lane M, pI markers; lane 1, PL I; lane 2, PL II. Numbers at the left indicate $\mathrm{pH}$ of $\mathrm{p} I$ markers.

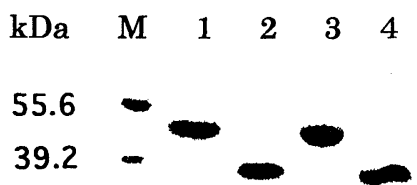

Fig. 5. SDS-PAGE of deglycosylated PLs I and II from S. purpureum.

Each sample was electrophoresed on a SDSpolyacrylamide gel. Lane M, molecular mass markers; lane 1, native PL I; lane 2, deglycosylated PL I; lane 3, native PL II; lane 4, deglycosylated PL II. Numbers at the letf indicate molecular mass markers in $\mathrm{kDa}$. 
Table 2. Amino acid composition of PLs I and II from S. purpureum.

\begin{tabular}{|c|c|c|c|c|}
\hline \multirow{2}{*}{ Amino acid } & \multicolumn{2}{|c|}{ S. purpureum } & \multirow{2}{*}{$\frac{\text { E. carotovora }}{\text { PL I }}$} & \multirow{2}{*}{ EndoPG I } \\
\hline & PL I & PL II & & \\
\hline & \multicolumn{4}{|c|}{ Mole percent $(\%)$} \\
\hline Ala & 6.8 & 6.7 & 10.1 & 8.0 \\
\hline Arg & 2.8 & 2.7 & 3.3 & 1.3 \\
\hline Asp & 16.8 & 16.9 & 17.2 & 16.4 \\
\hline Cys & 0.6 & 0.4 & 3.2 & 1.5 \\
\hline Glu & 6.9 & 6.9 & 3.4 & 3.6 \\
\hline Gly & 13.3 & 13.2 & 10.6 & 13.6 \\
\hline His & 3.0 & 3.0 & 1.6 & 1.8 \\
\hline Ile & 5.7 & 5.8 & 6.8 & 3.9 \\
\hline Leu & 8.3 & 7.8 & 4.7 & 6.4 \\
\hline Lys & 2.7 & 2.6 & 7.5 & 6.2 \\
\hline Met & 0.4 & 0.4 & 0.6 & 0.8 \\
\hline Phe & 3.5 & 3.5 & 2.6 & 3.1 \\
\hline Pro & 2.3 & 2.2 & 3.0 & 5.7 \\
\hline Ser & 6.7 & 7.0 & 6.6 & 7.2 \\
\hline Thr & 8.6 & 9.0 & 6.8 & 11.1 \\
\hline Yyr & 1.6 & 1.6 & 4.3 & 1.5 \\
\hline Val & 9.6 & 9.7 & 6.5 & 6.7 \\
\hline
\end{tabular}

${ }^{a}$ From $S$. purpureum. ${ }^{28)}$

(A)

\section{Enzyme characteristics.}

The PLs exhibited similar optima pHs of around 9.5. The $\mathrm{pH}$ and thermal stabilities were investigated by measuring the residual activities of these enzymes. The PLs were shown to be stable for 10 $\mathrm{h}$ at $30^{\circ} \mathrm{C}$ in the $\mathrm{pH}$ range between 6.0 to 7.0 , and for 15 min below $50^{\circ} \mathrm{C}$ at $\mathrm{pH} 6.0$. Although PL I lost its activity, PL II retained $30 \%$ of its activity at $70^{\circ} \mathrm{C}$.

The effects of $\mathrm{Ca}^{2+}, \mathrm{Mg}^{2+}$, or $\mathrm{Mn}^{2+}$ ions and various reagents (EDTA, iodoacetamide, $N$ bromosuccinimide, $\mathrm{PCMB}$, and $\mathrm{HgCl}_{2}$ ) on the activities of PLs I and II were also investigated. Both PLs I and II required $0.2 \mathrm{mM} \mathrm{Ca}^{2+}$ ion for maximum activities. The addition of $\mathrm{Mg}^{2+}$ or $\mathrm{Mn}^{2+}$ ion, instead of $0.2 \mathrm{mM}$ of $\mathrm{Ca}^{2+}$ ion, decreased the activities of PL I to 9 and 25\%, respectively, and for PL II, 13 and 30\%, respectively. The activities of PLs I and II were completely inhibited by EDTA as well as many PLs reported so far. ${ }^{7)}$ Except for the iodoacetamide, which had no effect, the addition of $1 \mathrm{mM} N$-bromosuccinimide, PCMB, and $\mathrm{HgCl}_{2}$, completely inhibited the activities of PL. Similarly, E. carotovora PL I was seriously inhibited by EDTA, $N$-bromosuccinimide, PCMB,

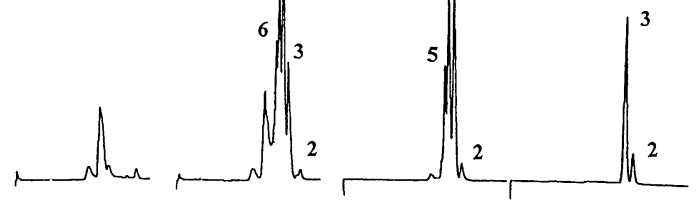

(B)

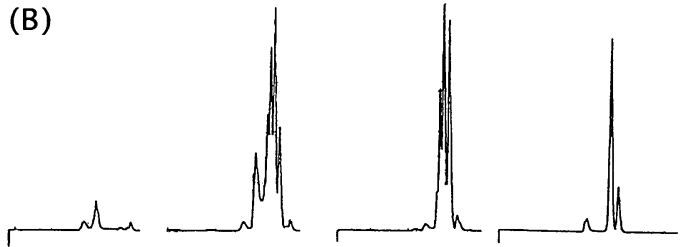

(C)

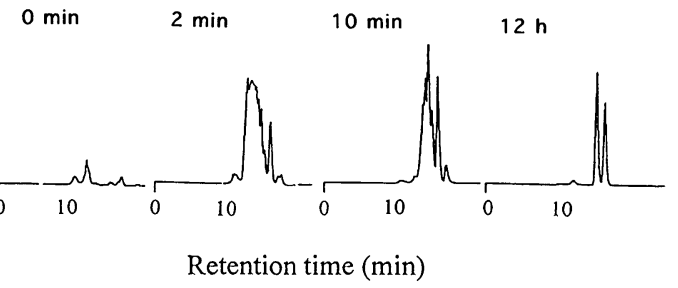

Fig. 6. HPLC analysis of reaction products by PLs I and II from S. purpureum and PL I from E. carotovora.

AIPA was used as the substrate for three PLs. The numbers of each peak in (A) indicate the DP of unsatd. GalUA. The reaction times of each diagram in (A), (B) and (C) were $0,2,10 \mathrm{~min}$ and $12 \mathrm{~h}$ from left. (A), S. purpureum PL I; (B), S. purpureum PL II; (C), E. carotovora PL I. 
and $\mathrm{HgCl}_{2}$. However, in contrast, an inhibition of $60 \%$ was effected by iodoacetamide, which had no effect on S. purpureum PL. S. purpureum PLs are different in their inhibitory effects on the activity from E. carotovora PL.

\section{Analysis of the reaction products.}

Although HPLC analyses of the reaction products, which showed oligo-GalUAs in the initial stage of the reaction (Figs. $6 \mathrm{~A}, \mathrm{~B}$ ), indicate that these enzymes function as endo-types, these PLs produced only 4,5-unsatd. oligo-GalUA that were below octa-GalUA. Since this result was different from products in the initial stage of $E$. carotovora PL I, which is a typical endo-type (Fig. $6 \mathrm{C}$ ), $S$. purpureum PLs may represent a new class of the enzymes. After $24 \mathrm{~h}$, analysis of the reaction products indicated a major peak for 4,5-unsatd. triGalUA (84\%) and a minor peak for unsatd. diGalUA (16\%). The ratios of these products were identical for PLs I and II. Thus PLs I and II seem to be incapable of acting on substrates below unsatd. tri-GalUA. In contrast, the final products of E. carotovora PL were also unsatd. tri- and diGalUAs but with a reaction product ratio of 58 and $42 \%$, respectively.

\section{REFERENCES}

1 ) K. Miyairi, M. Senda, M. Watanabe, Y. Hasui and T. Okuno: Cloning and sequence analysis of cDNA encoding endopolygalacturonase I from Stereum purpureum. Biosci. Biotechnol. Biochem., 61, 655-659 (1997).

2 ) Y. Hasui, Y. Fukui, J. Kikuti, N. Kato, K. Miyairi and T. Okuno: Isolation, characterization, and sugar chain structure of endoPG Ia, Ib, and Ic from Stereum purpureum. Biosci. Biotechnol. Biochem., 62, 852-857 (1998).

3 ) T. Shimizu, K. Miyairi and T. Okuno: Determination of glycosylation sites, disulfide bridges and C-terminal of Stereum purpureum mature endopolygalacturonase I by electrospray ionization mass spectrometry. Eur. J. Biochem., 267, 2380-2388 (2000).

4 ) K. Miyairi: Biochemical studies on the silver-leaf inducing substance of apple silver-leaf disease. Bull. Fac. Agric. Hirosaki Univ., 49, 61-148 (1988).

5 ) J. Sugiura, M. Yasuda, S. Kamimiya, K. Izaki and H. Takahashi: Purification and properties of two pectate lyase produced by Erwinia carotovora. J. Gen. Appl.
Microbiol., 30, 167-175 (1984).

6 ) P. Quantick, F. Cervone and R.K.S. Wood: Isoenzymes of a polygalcturonate trans-eliminase produced by Erwinia atroseptica in potato tissue and in liquid culture. Physiol. Plant Pathol., 22, 77-86 (1983).

7 ) Y. Miyazaki: Purification and characterization of endopectate lyase from Bacillus macerans. Agric. Biol. Chem., 55, 25-30 (1991).

8 ) W. Nasser, A.C. Awade, S. Reverchon and J. RobertBaudouy: Pectate lyase from Bacillus subtilis: Molecular characterization of the gene, and properties of the cloned enzyme. FEBS Lett., 335, 319-326 (1993).

9 ) C-H. Liao, H.Y. Hung and A.K. Chatterjee: Cloning of pectate lyase gene pel from Pseudomonas fluorescens and detection of sequences homologous to pel in Pseudomonas viridiflava and Pseudomonas putida. J. Bacteriol., 173, 4386-4393 (1991).

10) N. Nikaidou, Y. Kamio and K. Izaki: Molecular cloning and nucleotide sequence of the pectate lyase gene from Pseudomonas marginalis N6301. Biosci. Biotechnol. Biochem., 57, 957-960 (1993).

11) S. Nasuno and M.P. Starr: Polygalacturonic acid transeliminase of Xanthomonas campestris. Biochem. J., 104, 178-185 (1967).

12) A.R. Dean and E.W. Timberlake: Regulation of the Aspergillus nidulans pectate lyase gene (pelA). Plant Cell, 1, 275-284 (1989).

13) J.G. Hancok: Multiple forms of endo-pectate lyase formed in culture and in infected squash hypocotyls by Hyphomyces solani f. sp. cucurbite. Phytopathology, 66, 40-45 (1976).

14) W.A. Ayers, G.C. Papavizas and A.F. Diem: Polygalacturonate trans-eliminase and polygalacturonase production by Rhizoctonia solani. Phytopathology, 56, 1006-1011 (1996).

15) L. Gonzalez-Candelas and P.E. Kolattukudy: Isolation and analysis of a novel inducible pectate lyase gene from the phytopathogenic fungus Fusarium solani f. sp. pisi. J. Bacteriol., 174, 6343-6349 (1992).

16) J.A.E. Benen, H.C.M. Kester, L. Parenicova and J. Visser: Characterization of Aspergillus niger pectate lyase A. Biochemistry, 39, 15563-15569 (2000).

17) J. Ozawa: Pectic substance. Tanpakushitsu Kakusan Koso (in Japanese), 15, 888-894 (1970).

18) K. Nozaki, K. Miyairi, S. Hozumi, Y. Fukui and T. Okuno : Novel exopolygalacturonases produced by $\mathrm{Al}$ ternaria mali. Biosci. Biotechnol. Biochem., 61, 7580 (1997).

19) C.W. Nagel and M.M. Anderson: Action of a bacterial transeliminase on normal and unsaturated oligogalacturonic acids. Arch. Biochem. Biophys., 112, 322-330 (1965).

20) O.H. Lowry, N.J. Rosebrough, A.L. Farr and R.J. Randall: Protein measurement with the folin phenol reagent. J. Biol. Chem., 193, 265-275 (1951).

21) U.K. Laemmli: Cleavage of structural proteins during 
the assembly of bacteriophage T4. Nature, 227, 680685 (1970).

22 ) H. Sassa, H. Hirano and H. Ikehashi: Selfincompatibility-related RNases in styles of Japanese pear. Plant Cell Physiol., 33, 811-814 (1992).

23) H. Tanabe, Y. Kobayashi, Y. Matuo, N. Nishi and F. Wada: Isolation and fundamental properties of endopectate lyase $\mathrm{p} I$-isozymes from Erwinia carotovora. Agric. Biol. Chem., 48, 2113-2120 (1984).

24) C. Hatanaka, K. Yokohiki and S. Matsuhashi: Analysis of galacturonic acid and oligogalacturonic acids by high-performance liquid chromatography. J. Fac. Appl. Biol. Sci., Hiroshima Univ., 25, 41-48 (1986).

25) N.T. Keen, D. Dahlbeck, B. Staskawicz, and W. Belser: Molecular cloning of pectate lyase genes from Erwinia chrysanthemi and their expression in Escherichia coli. J. Bacteriol., 159, 825-831 (1984).

26) A. Kotoujansky: Molecular genetics of pathogenesis by soft-rot Erwinias. Ann. Rev. Phytopathol., 25, 405-430 (1987).

27) M.N. Rao, A.A. Kembhavi and A. Pant: Role of lysine, tryptophan and calcium in the $\beta$-elimination activity of a low-molecular-mass pectate lyase from Fusarium moniliformae. Biochem. J., 319, 159-164 (1996).

28) K. Miyairi, M. Toyoda and T. Okuno: Purification and characterization of endo- and exopolygalacturonases from Fomitopsis cytisina. J. Appl. Glycosci., 48, 105-114 (2001).

(Received July 16, 2001; Accepted October 1, 2001)
銀葉病菌のペクチン酸リアーゼ I と I の

精製と性質

宮入一夫, 西田佳織, 宝栄 優 鹿内由美子, 奥野智旦

弘前大学農学生命科学部応用生命工学科 (036-8561 弘前市文京町 3)

リンゴ銀葉菌の培養口液からペクチン酸リアーゼ I と II (PL I, II) を SDS-PAGE 的に均一成分として単離 した.これらの分子質量は $48 \mathrm{kDa}$ で等しく, Endo $\mathrm{H}$ 処理によりともに $38 \mathrm{kDa}$ に隇少した.また, 等電点は それぞれ 4.15 と 4.10 であった. $\mathrm{N}$ 末端アミノ酸 20 残 基は共通であり，アミノ酸組成もきわめて似ていた.

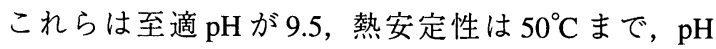
安定性は $\mathrm{pH}$ 6.0-7.0 とほほ同じであり, $0.2 \mathrm{mM} \mathrm{Ca}^{2+}$ 存在下で最大活性を示した. 反応生成物の HPLC 分 析で, 反応初期からオリゴガラクッロン酸を生成した ことからエンド型と推定されたが，E. carotovora PL による生成物パターンとは異なっていた，また，反応 最終産物は不飽和のジとトリガラクツロン酸であった が, その比率は E. carotovora PLの場合とは異なって いた。 